\title{
In vitro evaluation of Different Fungicides against Alternaria alternata Causing Leaf and Fruit Spot in Pomegranate
}

\author{
Vasudha A. Kadam*, D.N. Dhutraj and D.V. Pawar \\ Department of Plant Pathology, V.N.M.K.V. Parbhani-431402 (M.S.), India \\ *Corresponding author
}

\section{A B S T R A C T}

\begin{tabular}{|l|}
\hline Ke y w or d s \\
$\begin{array}{l}\text { Pomegranate (Punica } \\
\text { granatum L.), } \\
\text { Xanthomonas axonopodis } \\
\text { pv. punicae }\end{array}$ \\
\hline Article Info \\
\hline $\begin{array}{l}\text { Accepted: } \\
18 \text { September } 2018 \\
\text { Available Online: } \\
10 \text { October } 2018\end{array}$ \\
\hline
\end{tabular}

\section{Introduction}

Pomegranate (Punica granatum L.) is an important horticultural crop of India and cultivated both for domestic market and export purposes and a valued crop for consumption, medicinally as well as commercial purposes.

India is the largest pomegranate growing (2.09 lakh ha) and producing (24.42 lakh MT) country of the world and Maharashtra is the leading state in acreage covering about 68.7 per cent of the area under pomegranate.

Similarly around 70.2 per cent of total production comes from Maharashtra (Anonymous, 2016).

\begin{abstract}
Pomegranate (Punica grantum L.) is a high value commercial horticultural crop grown extensively throughout Maharashtra. Among the different diseases on pomegranate Alternaria leaf and fruit spot caused by Alternaria alternata (Fr.) Keissler, is becoming a serious and emerging problem to growers in Maharashtra. Therefore, in present studies fungicides (six systemic, five non systemic and two combi fungicides) were tested in vitro against A. alternata. Among systemic fungicides, average cent per cent inhibition of mycelial growth was with Propiconazole (100\%) followed by Hexaconazole $(99.38 \%$ ), Penconazole (90.74\%) and Difenconazole (85.80\%). Among non-systemic and combigicides, significantly highest average mycelial growth inhibition was with Carbendazim 12 WP + Mancozeb 63 WP (81.39\%), followed by Mancozeb (78.05 \%), Copperoxychloride (70.13\%) and Copper-hydroxide (66.79\%).
\end{abstract}

The maintenance of quality and quantity of the crop is deteriorated by certain diseases. Pomegranate is affected by number of serious diseases caused by fungi, bacteria and nematodes such as bacterial blight (Xanthomonas axonopodis pv. punicae), wilt due to Ceratocystis fimbriata, anthracnose (Colletotrichum gloeosporioides) and leaf spot and severe fruit rotting due to Alternaria alternata, Cercospora sp., Pseudocercospora sp., Drechslera sp. and Sphacelomasp. etc., are more or less equally important and harmful in some orchards and also take a heavy toll on the crop (Khosla and Bhardwaj, 2013). Among the several leaf spot and fruit spot/rotting fungi on pomegranate Alternaria alternata (Fr.) Keissler has caused severe infections and a major limiting factor in 
cultivation of pomegranate in some regions of India, requiring immediate attention. The pathogen A. alternata responsible for leaf spot on pomegranate was first reported in India by Madhukar and Reddy (1976) and subsequently from USA, Mexico (Farr et al., 2007). Leaf spot and fruit rot (A. alternata) on pomegranate has been noticed in northern Karnataka 15-80 per cent disease incidence (Archana and Jamadar, 2014). In Himachal Pradesh incidence of leaf and fruit spots were caused by Alternaria alternate showing incidence of 17.31 per cent (Khosla and Bhardwaj, 2013). The disease has remained unexplored but potentially dangerous and an emerging disease on pomegranate. Therefore, keeping all these aspects in view present studies was aimed to determine the efficacies of different doses of fungicides under in vitro against Alternaria leaf and fruit spot of pomegranate.

\section{Materials and Methods}

Efficacy of six systemic fungicides and six non-systemic / combi fungicides was evaluated in vitro at various concentrations against A. alternata, applying Poisoned food technique (Nene and Thapliyal, 1993) and using Potato dextrose agar (PDA) as basal culture medium. Systemic fungicides at the rate 500, 1000 and 1500 ppm while Nonsystemic and combi- fungicides at the rate 1000, 2000 and 2500 ppm.

Based on active ingredient, requisite quantity of the test fungicides was calculated, mixed separately thoroughly with autoclaved and cooled $\left(40^{\circ} \mathrm{C}\right)$ PDA medium in conical flasks to obtain desired concentrations. This PDA medium amended separately with the test fungicides was then poured $(20 \mathrm{ml} /$ plate $)$ aseptically in Petri plates (90 $\mathrm{mm}$ dia.) and allowed to solidify at room temperature. For each of the test fungicide and its desired concentrations, three plates / treatment / replication were maintained. After solidification of the PDA medium, all the plates were inoculated aseptically by placing in the centre a $5 \mathrm{~mm}$ culture disc obtained from actively growing 7 days old pure culture of A. alternata and incubated in an inverted position at $27 \pm 2{ }^{0} \mathrm{C}$. Petri plates filled with plain PDA (without any fungicide) and inoculated with the pure culture disc of $A$. alternata were maintained as untreated control.

Observations on radial mycelial growth / colony diameter were recorded at an interval of 24 hours and continued till untreated control plates were fully covered with mycelial growth of the test pathogen. Per cent inhibition of the test pathogen with the test fungicides over untreated control was calculated by applying following formula (Vincent, 1927).

Per cent inhibition= $\frac{\mathrm{C}-\mathrm{T}}{\mathrm{C}}$

Where,

$\mathrm{C}=$ growth of the test fungus in untreated control plates

$\mathrm{T}=$ growth of the test fungus in treated plates

\section{Results and Discussion}

\section{In vitro evaluation of systemic fungicides}

Results (Plate 1 and Table 1) revealed that all the systemic fungicides tested (each @ 500, 1000 and 1500 ppm) significantly inhibited mycelial growth of A. alternata, over untreated control. Further, per cent mycelial inhibition was increased with increase in concentrations of the fungicides tested (Fig. 1).

Average percentage mycelial growth 
inhibition recorded with all the systemic fungicides tested was ranged from 38.08 (Thiophanate methyl) to 100 (Propiconazole). Propiconazole was found cent percent (100\%) inhibition. However, Hexaconazole and Penconazole were found highly fungistatic and both of which recorded significantly highest average mycelial inhibition of 99.38 and 90.74 per cent. Followed by Difenconazole (85.80\%). Fungicides Thiophanate methyl (38.08 \%) and Carbendazim $(47.84 \%)$ were found less effective.

Thus, all the systemic fungicides tested were found fungistatic against A. alternata and significantly inhibited its mycelial growth over untreated control. However, fungicides found most effective in the order of merit were Propiconazole, Hexaconazole, Penconazole and Difenconazole. These results are in agreement with Suryawanshi et al., (2010) who reported Propiconazole as best fungicide in inhibiting the mycelial growth and sporulation of A. alternata infecting pomegranate fruits. Archana (2012) found that Propiconazole at different concentrations $(0.1 \%, 0.2 \%$ and $0.3 \%)$ completely inhibited the mycelial growth of $A$. alternata in pomegranate which was superior over hexaconazole and Difenconazole.

These results are in conformity with the earlier findings of those workers who reported systemic fungicides viz., Propiconazole, Hexaconazole, Penconazole, Difenconazole, Carbendazim and Thiophanate methyl at various concentrations had significantly inhibited mycelial growth of A. alternata infecting, chrysanthemum (Arunkumar, 2008), infecting turmeric (Gorawar and Hegde, 2005), infecting Groundnut (Bhaskar and Lukose, 2012), infecting Gerbera (Apet et al., 2014) and A. alternata infecting sesame (Bavaji et al., 2012).

Table.1 In vitro evaluation of systemic fungicides against mycelial growth of A. alternata

\begin{tabular}{|c|c|c|c|c|c|}
\hline \multirow{2}{*}{$\begin{array}{l}\text { Tr. } \\
\text { No. }\end{array}$} & \multirow[t]{2}{*}{ Treatments } & \multicolumn{3}{|c|}{$\%$ Inhibition* at ppm } & \multirow{2}{*}{$\begin{array}{l}\text { Av. } \\
(\%)\end{array}$} \\
\hline & & 500 & 1000 & 1500 & \\
\hline $\mathbf{T}_{1}$ & Carbendazim50 WP & $\begin{array}{l}40.19 \\
(39.32)\end{array}$ & $\begin{array}{c}49.26 \\
(44.56)\end{array}$ & $\begin{array}{c}54.07 \\
(47.32)\end{array}$ & $\begin{array}{r}47.84 \\
(43.73)\end{array}$ \\
\hline $\mathbf{T}_{2}$ & Propiconazole $25 \mathrm{EC}$ & $\begin{array}{l}100.00 \\
(90.00)\end{array}$ & $\begin{array}{l}100.00 \\
(90.00)\end{array}$ & $\begin{array}{l}100.00 \\
(90.00)\end{array}$ & $\begin{array}{l}100.00 \\
(90.00)\end{array}$ \\
\hline $\mathbf{T}_{3}$ & Hexaconazole 5 EC & $\begin{array}{c}98.15 \\
(85.44)\end{array}$ & $\begin{array}{l}100.00 \\
(90.00)\end{array}$ & $\begin{array}{l}100.00 \\
(90.00)\end{array}$ & $\begin{array}{c}99.38 \\
(88.48)\end{array}$ \\
\hline $\mathbf{T}_{4}$ & Difenconazole $25 \mathrm{EC}$ & $\begin{array}{r}82.96 \\
(65.61)\end{array}$ & $\begin{array}{l}85.00 \\
(67.19)\end{array}$ & $\begin{array}{c}89.44 \\
(71.02)\end{array}$ & $\begin{array}{c}85.80 \\
(67.94)\end{array}$ \\
\hline $\mathbf{T}_{5}$ & Penconazole $10 \mathrm{EC}$ & $\begin{array}{c}86.11 \\
(68.10)\end{array}$ & $\begin{array}{c}89.81 \\
(71.38)\end{array}$ & $\begin{array}{r}96.30 \\
(80.89)\end{array}$ & $\begin{array}{c}90.74 \\
(73.45)\end{array}$ \\
\hline $\mathbf{T}_{6}$ & $\begin{array}{l}\text { Thiophanate methyl } \\
\text { 70WP }\end{array}$ & $\begin{array}{c}29.81 \\
(33.08)\end{array}$ & $\begin{array}{c}39.07 \\
(38.67)\end{array}$ & $\begin{array}{c}45.37 \\
(42.33)\end{array}$ & $\begin{array}{c}38.08 \\
(38.02)\end{array}$ \\
\hline $\mathbf{T}_{0}$ & Control (Untreated) & $\begin{array}{c}0.00 \\
(0.00)\end{array}$ & $\begin{array}{c}0.00 \\
(0.00)\end{array}$ & $\begin{array}{c}0.00 \\
(0.00)\end{array}$ & $\begin{array}{c}0.00 \\
(0.00)\end{array}$ \\
\hline & S.E. \pm & 1.79 & 0.37 & 1.74 & 1.30 \\
\hline & C.D. $(P=0.01)$ & 5.47 & 1.13 & 5.32 & 3.97 \\
\hline & & 5.67 & 1.11 & 5.00 & 3.93 \\
\hline
\end{tabular}

*: Mean of three replications, Dia: Diameter, Av.: Average

Figures in parentheses are arcsine transformed values 
Table.2 In vitro evaluation of non-systemic fungicides against mycelial growth of A. alternata

\begin{tabular}{|c|c|c|c|c|c|}
\hline \multirow{2}{*}{$\begin{array}{l}\text { Tr. } \\
\text { No. }\end{array}$} & \multirow[t]{2}{*}{ Treatments } & \multicolumn{3}{|c|}{ \% Inhibition* at ppm } & \multirow{2}{*}{$\begin{array}{l}\text { Av. } \\
(\%)\end{array}$} \\
\hline & & 1000 & 2000 & 2500 & \\
\hline$\overline{T_{7}}$ & Chlorotholonil & $\begin{array}{c}46.97 \\
(44.66)\end{array}$ & $\begin{array}{c}49.44 \\
(46.15)\end{array}$ & $\begin{array}{c}54.01 \\
(48.92)\end{array}$ & $\begin{array}{c}50.14 \\
(46.58)\end{array}$ \\
\hline$T_{8}$ & $\begin{array}{l}\text { Ridomil MZ } \\
72 \mathrm{WP}\end{array}$ & $\begin{array}{c}53.31 \\
(48.49)\end{array}$ & $\begin{array}{c}53.48 \\
(51.62)\end{array}$ & $\begin{array}{c}58.41 \\
(51.62)\end{array}$ & $\begin{array}{c}55.07 \\
(49.57)\end{array}$ \\
\hline$\overline{T_{9}}$ & $\begin{array}{l}\text { Carbendazim } 12 \text { WP + } \\
\text { Mancozeb } 63 \text { WP }\end{array}$ & $\begin{array}{c}78.81 \\
(65.60)\end{array}$ & $\begin{array}{c}80.05 \\
(71.39)\end{array}$ & $\begin{array}{c}85.32 \\
(71.39)\end{array}$ & $\begin{array}{r}81.39 \\
(67.86)\end{array}$ \\
\hline $\mathbf{T}_{10}$ & $\begin{array}{l}\text { Copper-oxychloride } \\
\text { 50WP }\end{array}$ & $\begin{array}{c}64.21 \\
(55.28)\end{array}$ & $\begin{array}{c}71.25 \\
(62.63)\end{array}$ & $\begin{array}{c}74.94 \\
(62.63)\end{array}$ & $\begin{array}{c}70.13 \\
(59.30)\end{array}$ \\
\hline$T_{11}$ & $\begin{array}{l}\text { Copper-hydroxide } \\
77 \text { WP }\end{array}$ & $\begin{array}{c}61.22 \\
(53.38)\end{array}$ & $\begin{array}{c}68.61 \\
(59.49)\end{array}$ & $\begin{array}{c}70.55 \\
(59.49)\end{array}$ & $\begin{array}{r}66.79 \\
(57.01)\end{array}$ \\
\hline$T_{12}$ & $\begin{array}{l}\text { Mancozeb } \\
75 \mathrm{WP}\end{array}$ & $\begin{array}{c}74.42 \\
(62.24)\end{array}$ & $\begin{array}{c}78.11 \\
(67.95)\end{array}$ & $\begin{array}{c}81.63 \\
(67.95)\end{array}$ & $\begin{array}{r}78.05 \\
(65.08) \\
\end{array}$ \\
\hline$T_{13}$ & $\begin{array}{l}\text { Propineb } \\
70 \mathrm{WP}\end{array}$ & $\begin{array}{c}57.35 \\
(50.97)\end{array}$ & $\begin{array}{c}61.75 \\
(56.65)\end{array}$ & $\begin{array}{c}66.32 \\
(56.65)\end{array}$ & $\begin{array}{c}61.81 \\
(53.78)\end{array}$ \\
\hline$T_{0}$ & $\begin{array}{l}\text { Control } \\
\text { (Untreated) }\end{array}$ & $\begin{array}{c}0.00 \\
(0.00)\end{array}$ & $\begin{array}{c}0.00 \\
(0.00)\end{array}$ & $\begin{array}{c}0.00 \\
(0.00)\end{array}$ & $\begin{array}{c}0.00 \\
(0.00)\end{array}$ \\
\hline & S.E. \pm & 0.35 & 0.36 & 0.43 & \\
\hline & C.D. $(P=0.01)$ & 1.05 & 1.09 & 1.29 & \\
\hline & & 1.27 & 1.26 & 1.41 & \\
\hline & & 0.35 & 0.36 & 0.43 & \\
\hline
\end{tabular}

*: Mean of three replications, Dia: Diameter, Av.: Average

Figures in parentheses are arcsine transformed values

Fig.1 Bioefficacy of systemic fungicides against A. alternata

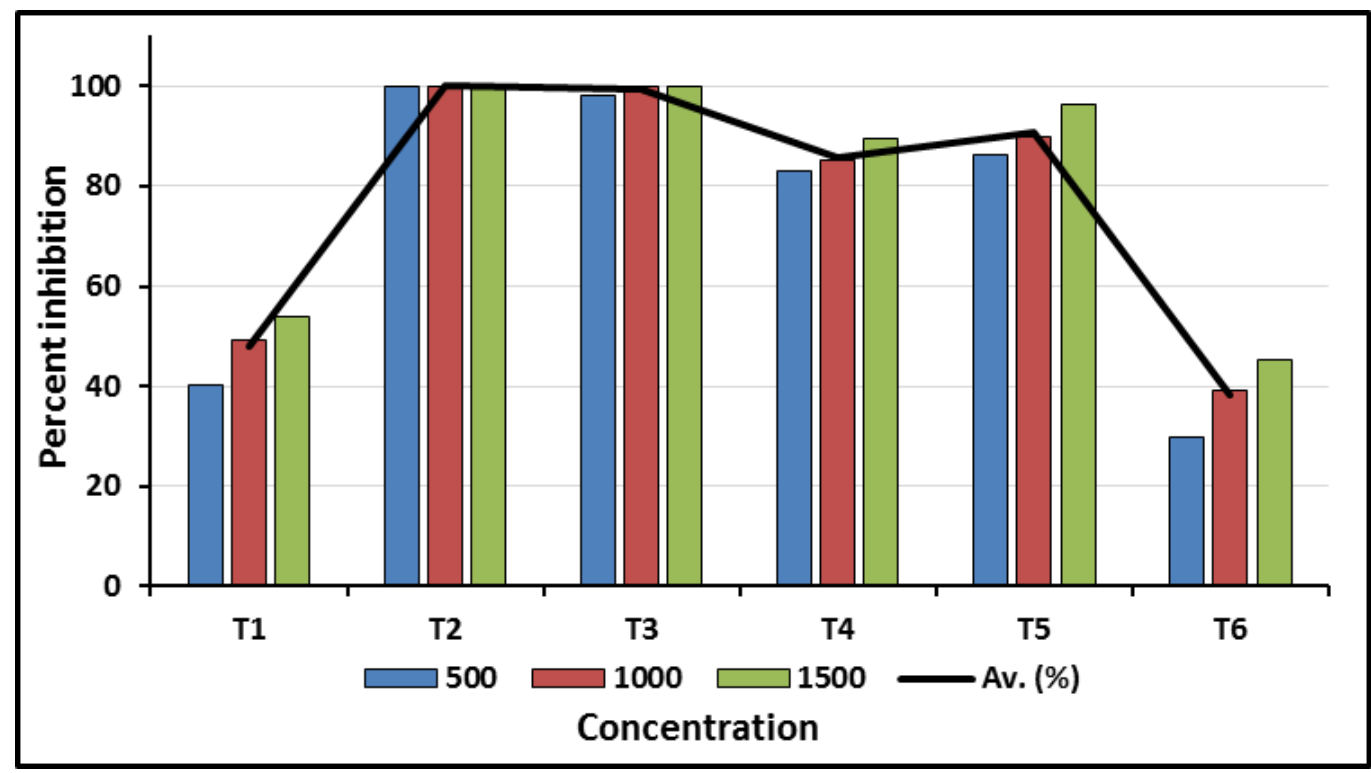


Fig.2 Bioefficacy of non-systemic and combi- fungicides against A. alternata

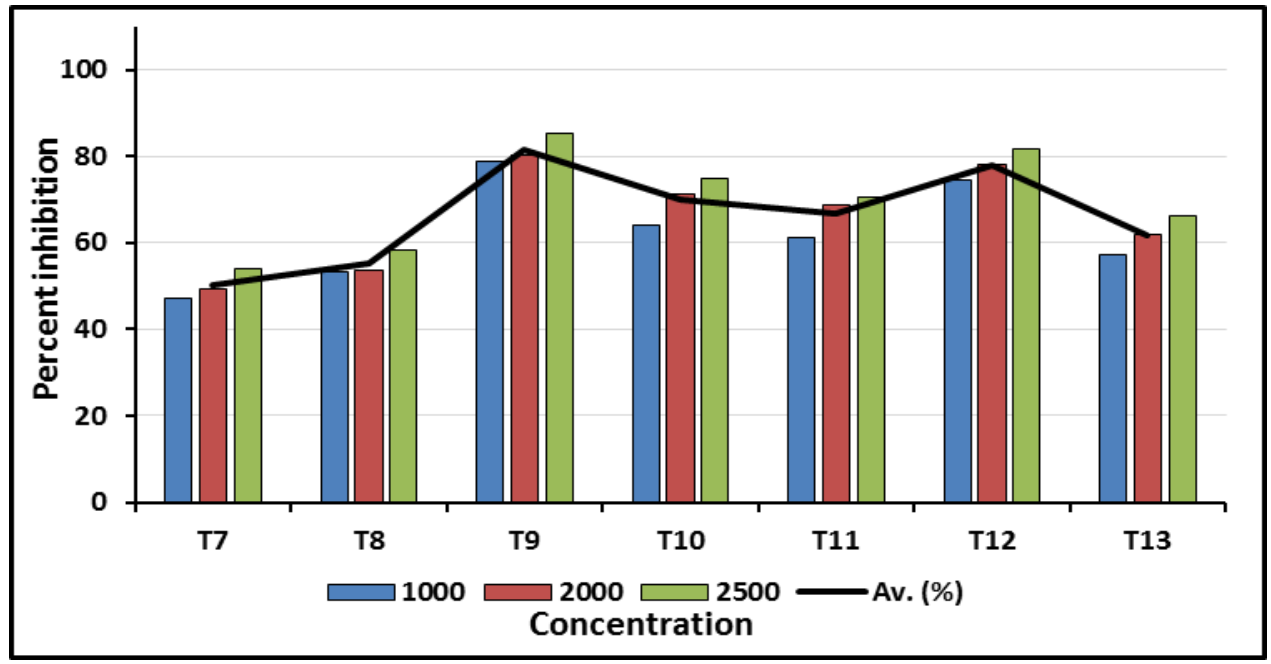

Plate.1 In vitro bioefficacy of systemic against $A$. alternata

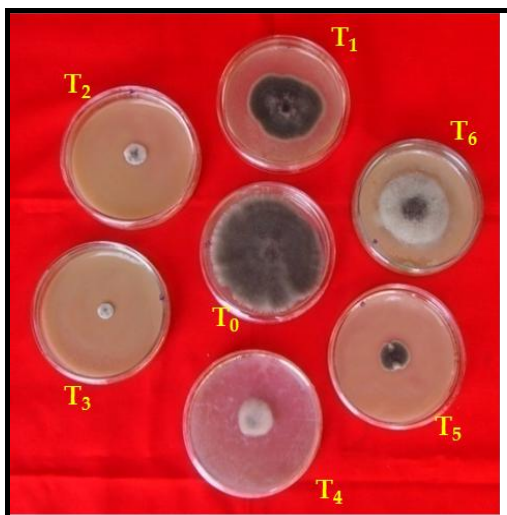

500 ppm (A)

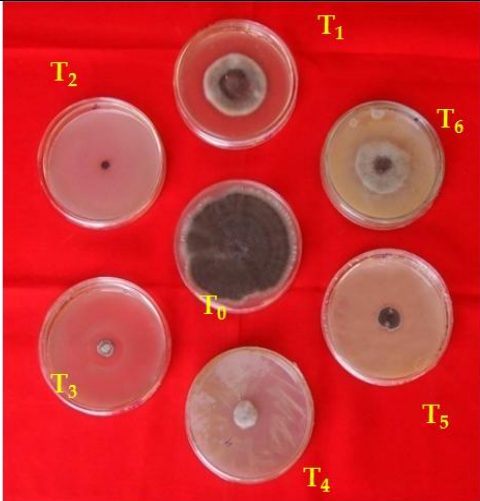

1000 ppm (B)

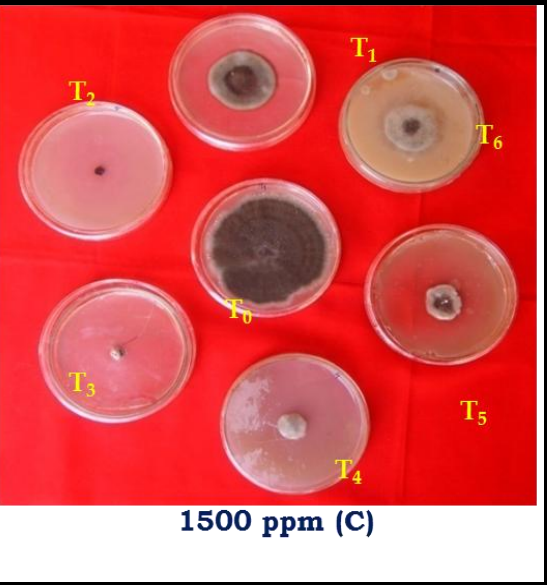

Plate.2 In vitro bioefficacy of non-systemic and combi - fungicides against A. alternata

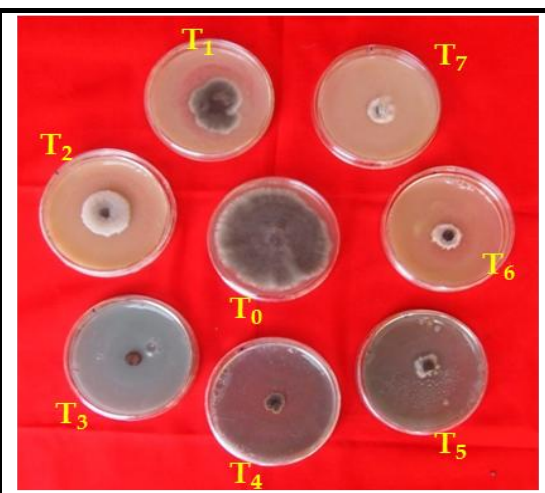

1000 ppm (A)

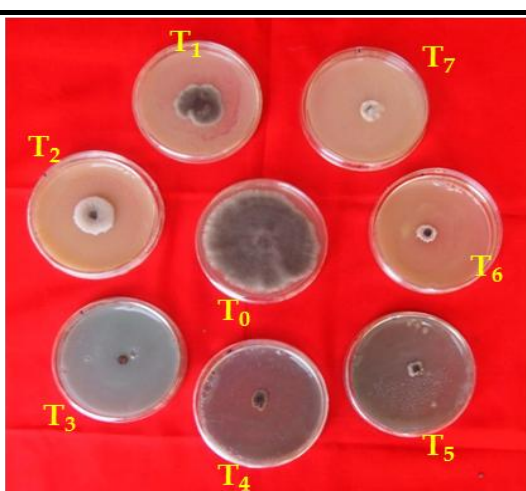

2000 ppm (B)

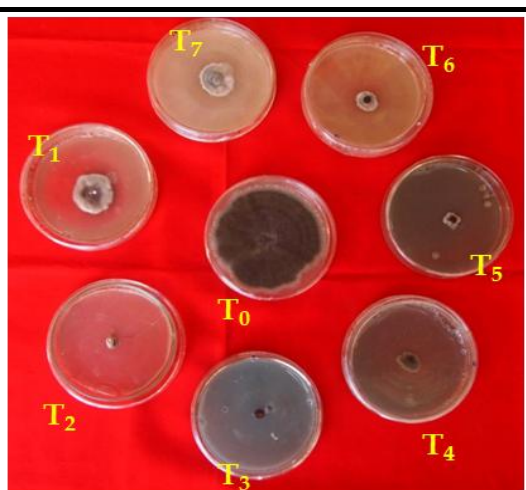

2500 ppm (C) 
In vitro evaluation of non-systemic and combi - fungicides

Results (Plate 2 and Table 2) revealed that all non-systemic and combi- fungicides tested (each @ 1000, 2000 and 2500 ppm) significantly inhibited mycelial growth of $A$. alternata, over untreated control. Further, per cent mycelial inhibition was increased with increase in concentrations of the fungicides tested (Fig. 2).

Average mycelial growth inhibition recorded with the test non-systemic and combifungicides was ranged from 50.14 (Chlorotholonil) to 81.39 (Carbendazim 12 WP + Mancozeb 63 WP) per cent. However, it was highest average mycelial growth inhibitionwith Carbendazim 12 WP + Mancozeb 63 WP (81.39\%), followed by Mancozeb (78.05 \%), Copper-oxychloride (70.13 \%), Copper-hydroxide (66.79\%), Propineb (61.81\%), Ridomil MZ (55.07\%) and Chlorotholonil (50.14 \%).

Non-systemic fungicides viz., Mancozeb, Copper-oxychloride, Copper hydroxides, Propineb and Chlorothalonil and Combifungicides (systemic + contact) viz., Carbendazim + Mancozeb, RidomilMZ were also reported to cause cent-per cent or significantly maximum mycelial growth inhibition of $A$. alternata infecting pomegranate (Archana 2012), A. macrospora infecting cotton (Gholve et al., 2014), A. solani infecting tomato (Nikam et al., 2014) and $A$. porri infecting onion (Kareem et al., 2012). Khursheed et al., (2016) reported that Carbendazim + Mancozeb completely (100\%) had the maximum inhibitory effect on sporolution and colony growth of A.mali infecting apple.

Thus, six systemic, five non-systemic and two combi- fungicides tested were found fungistatic against $A$. alternata. However, on the basis of order of merit systemic fungicides viz., Propiconazole, Hexaconazole, Penconazole and Difenconazole and nonsystemic / combi fungicides Carbendazim 12 WP + Mancozeb 63 WP (SAAF 75 WP), RidomilMZ, Mancozeb, Copper-oxychloride, Copper-hydroxide, Propineb and Ridomiletc were found most promising against $A$. alternata, causing leaf spot in pomegranate.

Among the fungicides tested, Propiconazole, Hexaconazole, Penconazole (systemic), Carbendazim 12 WP + Mancozeb 63 WP (combi-fungicides) and Mancozeb, Copper oxychloride, Copper hydroxide (nonsystemic) were most efficient with significantly highest inhibition of mycelial growth of the test pathogen Alternaria alternata causing leaf and fruit spot in pomegranate.

\section{References}

Anonymous (2016). Area and production of horticultural crop- All India. National horticultural board.

Apet, K.T., Jagdale, J. S., Mirza, F.N. Baigh, and Chavan, P. G. More, A. S. (2014). In vitroevaluation of fungicides, botanicals and bioagents against A.alternata, causing leaf spot of Gerbera. Trends in Biosci. 7(21): 33743382.

Archana B. C. (2012). Studies on leaf spot and fruit rot of Pomegranate caused by Alternaria alternata (Fr.) Keissler M.Sc. (Agri) (Degree) Plant Pathology (Department) University of Agricultural Sciences, Dharwad.

Archana, B. C. and M. M. Jamadar (2014). Management of leaf spot and fruit spot/rot of pomegranate (Punica granatum L.) caused by Alternaria alternata (Fr.) Keissler. Karnataka J. Agric. Sci., 27 (2): (247-249). 
Arunkumar G. S. (2008). Studies on leaf blight of chrysanthemum caused by Alternaria alternate (Fr.) Keissler. M.Sc. (Agri) Thesis, submitted to TNAU, Coimbatore.

Bavaji, M., Khamarjahan, M. D. and Mahendra Nath M. (2012). In vitro evaluation of fungicide and plant extracts on the incidence of leaf blight on Sesame caused by Alternaria alternata (FR) Keissler. Int. J. Food. Agric. Vet. Sci. 2(3): 105-107.

Bhaskar S.P. and Lukose C. (2012). Occurrence, development and management of Alternaria leaf blight in summer groundnut. (Abst.) J. Mycol. Pl. Pathol. 42 (1): 118.

Farr, D. F., Rossman, A. Y., Palm, M. E., McCray, E. B. (2007) Fungal diseases, Systematic Botany \& Mycology Laboratory, ARS, USDA. Retrieved February 5, 2007, from http://nt. arsgrin.gov/fungaldatabases/.

Gholve, V. M., Jogdand, S. M. and Suryawanshi, A. P. (2014). Evaluation of fungicides, botanicals and bioagents against Alternaria leaf blight caused by Alternaria macrospora in cotton. J. Cotton Res. Dev. 28 (2): 327-331.

Kareem, M. A., Krishnamurthy, K. V. M., Waseem, M. A. and Nadaf, H. A. (2012). Effect of biocontrol agents on growth and spore germination of $A$. porri. Bioinfolet. 9(3): 259-260.

Khosla Kishore and Bhardwaj S.S (2013). Occurrence and incidence of important diseases of pomegranate in Himachal Pradesh.Pl. Dis. Res. 28 (1):5-10.
Khosla Kishore and Bhardwaj S.S (2013). Occurrence and incidence of important diseases of pomegranate in Himachal Pradesh. Pl. Dis. Res. 28 (1):5-10.

KhursheedAalum, Imtiyaz Ahmad, Bharty Kumar, S.D Singh, Sujata Ganguly. (2016)Appliance of Fungicides on the Alternaria Leaf Spot Disease of Red Delicious Apple (Malus domestica Borkh.) Caused by the Pathogen, Aternariamali. Int. J. Inno. R. Sci., Eng and Techno. 5(7), 12748-12752.

Madhukar J, Reddy SM, (1976). Some new leaf spot diseases of pomegranate. Indian Journal of Mycology and Plant Pathology18, 171-2.

Nene, Y. L. and Thapliyal, P.N. (1993). Evaluation of fungicides. In: Fungicides in Plant disease Control ( $3^{\text {rd }}$ ed.) Oxford IBH publishing co., New Delhi. PP: 331.

Nikam, P. S., Suryawanshi, A. P. and Chavan, A. A. (2014) In vitro efficacy of systemic and non-systemic fungicides against Alternaria solani. J. Mycol. Pl. Pathol. 44(3): 349.

Suryawanshi, K. T., Sawant, D. M., Navale, A. M., Deokar, C. D. (2010). Studies on the pathogens associated with fruits of pomegranate (Punica granatum L.). Bioinfolet. 7(2): 1-8.

Tziros, G. T., Lagopodi, A. L., and TzavellaKlonari, K. 2007. Alternaria alternata fruit rot of pomegranate (Punica granatum) in Greece. New Dis. Rep. 15:14.

Vincent, J.M. (1927). Distortion of fungal hyphae in the presence of certain inhibitors Nature: 159-180.

\section{How to cite this article:}

Vasudha A. Kadam, D.N. Dhutraj and Pawar, D.V. 2018. In vitro evaluation of Different Fungicides against Alternaria alternata Causing Leaf and Fruit Spot in Pomegranate. Int.J.Curr.Microbiol.App.Sci. 7(10): 2292-2298. doi: https://doi.org/10.20546/ijcmas.2018.710.265 